anales de psicología, 2018, vol. 34, $\mathrm{n}^{\circ} 2$ (mav), 398-404 http://dx.doi.org/10.6018/analesps.34.2.289861
(C) Copyright 2018: Editum. Servicio de Publicaciones de la Universidad de Murcia. Murcia (Spain) ISSN print edition: 0212-9728. ISSN web edition (http://revistas.um.es/analesps): 1695-2294

\title{
Relationship among sociodemographic and sport variables, exercise dependence, and burnout: a preliminary study in athletes
}

\author{
Cristina Reche ${ }^{1 *}$, Cristina De Francisco ${ }^{1}$, Alejandro Martínez-Rodríguez ${ }^{2}$, and Almudena Ros-Martínez ${ }^{1}$ \\ 1 Universidad Católica de Murcia (Spain). \\ 2 Universidad de Alicante (Spain).
}

\begin{abstract}
Título: Relación entre variables sociodemográficas y deportivas, dependencia del ejercicio y burnout: un estudio preliminar en deportistas.

Resumen: El objetivo de estudio fue conocer la prevalencia de la sintomatología de dependencia al ejercicio físico y del burnout en deportistas, as como su relación con variables demográficas y deportivas. La muestra estaba formada por 449 deportistas españoles, 320 hombres y 129 mujeres (edad: $M=19.71 ; D T=6.62$ ) a los que se le administró las versiones españolas de la Escala de Dependencia del Ejercicio-Revisada y la versión reducida del Athlete Burnout Questionnaire. Los resultados de la prevalencia mostraron un riesgo de dependencia del ejercicio en el 8.7\% de los deportistas, con diferencias estadísticamente significativas en la edad (mayor dependencia en deportistas menores de 18 años), pero sin diferencias respecto al género, dedicación deportiva y tipo de deporte. Respecto al burnout, medido a través de sus tres dimensiones, las cifras de prevalencia se sitúan en $4 \%$ para agotamiento físico/emocional y $4.9 \%$ para devaluación de la práctica deportiva y para reducida sensación de logro. Los hombres y los practicantes de deportes colectivos presentan más reducida sensación de logro. Los hombres también refieren más devaluación de la práctica deportiva, al igual que los deportistas de más de 18 años. Los participantes que dedican menos tiempo a sus entrenamientos presentan mayores niveles de reducida sensación de logro, pero los que dedican más tiempo, presentan mayores niveles de agotamiento físico/emocional. Por último, sobre la relación dependencia al ejercicio físico y burnout, todas las dimensiones de burnout correlacionaron positivamente con la dependencia al ejercicio físico. Palabras clave: Dependencia; burnout; deportistas; prevalencia, variables sociodemográficas y deportivas.
\end{abstract}

\section{Introduction}

Physical exercise produces beneficial health effects (Lubans, Foster, \& Biddle, 2008), improving sense of well-being and state of mind (Ekkekakis \& Acevedo, 2006). People who exercise regularly tend to have higher levels of health and less stress, irrespective of the type of exercise (Jiménez, Martínez, Miró, \& Sánchez, 2008). Other benefits that can be seen are, relief from anxiety, antidepressant effects, increased selfesteem, self-efficacy and emotional regulation (Caracuel \& Arbinaga, 2010). However, in some cases, taking part in regular physical exercise can become a behavioural dependence leading to psychological addiction (Adams, Miller, \& Kraus, 2003) and a deterioration of state of mind (Guszkowska \& Rudnicki, 2012; Jones \& Tenenbaum, 2009).

Exercise addiction has been identified as having characteristics in common with DSM-5 criteria for behavioural addictions (Márquez \& De la Vega, 2015). Using the following criteria: a) Tolerance, an increase in the amount of exercise to achieve the desired effect; b) Withdrawal, negative effects

* Correspondence address [Dirección para correspondencia]:

Cristina De Francisco, Facultad de Ciencias Sociales y de la Comunicación, Departamento de Ciencias Sociales, Jurídicas y de la Empresa, Universidad Católica de Murcia, Avda. de los Jerónimos n¹35, 30107, Guadalupe, Murcia (Spain). E-mail: cdefrancisco@ucam.edu
Abstract: The aim of the study was to determine the prevalence of exercise dependence and athlete burnout and their relationship between them and among demographic and sport characteristics in a sample of 449 Spanish athletes, 320 males and 129 females (Age: $M=19.71 ; S D=6.62$ ). All of them replied the Spanish versions of Exercise Dependence ScaleRevised and reduced version of Athlete Burnout Questionnaire. Results of prevalence showed a risk of exercise dependence in $8.7 \%$ of the athletes, with statistically significant differences in age (greater exercise dependence was found in athletes under the age of 18 years old), not in gender, sport dedication and type of sport. Regarding burnout, measured through its three dimensions, the data of prevalence showed $4 \%$ for emotional/physical exhaustion and $4.9 \%$ for sport devaluation and reduced sense of accomplishment. Men and team-sport athletes showed a greater reduced sense of accomplishment. Men and athletes over the age of 18 also showed more sport devaluation. As for sport dedication, participants who spent less time training had higher levels of reduced sense of accomplishment, whereas those who dedicated more time had higher levels of emotional/physical exhaustion. Finally, the relationship between exercise dependence and burnout showed that all dimensions of burnout correlated positively with exercise dependence.

Keywords: Dependence; burnout; athletes; prevalence; sociodemographic and sport variables.

are experienced in the absence of exercise, such as anxiety, irritability or sleep problems; c) Lack of control and failure in attempts to reduce or cease exercise; d) Intention effects, an inability to adjust to a set routine; e) Excessive dedication to preparing for, engaging in, and recovering from exercise; $f$ ) Reduction of other social, occupational and / or recreational activities; g) Continuance, continuing to exercise despite knowing that this activity is creating problems.

Researchers have studied the effects of different sociodemographic variables on exercise dependence, but results are not conclusive. For example, studies report differences in exercise dependence in men and women depending on the assessment instrument used (Weik \& Hale, 2009): men show high levels of dependence when using the Exercise Dependence Scale (EDS), whereas the Exercise Dependence Questionnaire (EDP) gives an opposite result with women having greater dependence. Some authors even report no gender differences (Allegre, Therme, \& Griffiths, 2007; Lindwall \& Palmeira, 2009; Reche, Martínez-Rodríguez, \& Ortín, 2015). Also, there is some controversy about the age for the onset of the disorder. Most researchers agree that exercise dependence has a greater influence on young athletes (Allegre et al., 2007; Lindwall \& Palmeira, 2009; González-Cutre \& Sicilia, 2012). Others, however, have found no associations (Klein et al., 2004).

Effects of different basic sport variables have also been 
studied. In relation to sport modality (individual or team), Reche et al. (2015) show similar levels of dependence and Modolo, Mello, Gimenez, Tufik and Antunes (2009) report that there is a greater dependence in amateur athletes than in professional athletes. Sicilia and González-Cutre (2011), using the Spanish version of EDS-Revised (EDS-R), found that athletes who exercise more than 3 days a week (more sport dedication) scored higher on all subscales of dependence compared to athletes who took part less frequently. Other studies show that participants who do more than four hours of physical exercise per week show a higher overall average of exercise dependence compared to those who do less (Reche \& Gómez, 2014; Reche et al., 2015). So, exercise adherence and regularity could be considered as presenting characteristics. However, Kjelsas, Augestad and Götestam (2003) do not consider this enough to justify exercise dependence, and so a resolution to this dysfunctional aspect is still something open to discussion.

On the other hand, evidence has suggested that high levels of exercises may be responsible for the development of overtraining syndrome, a state which can lead to burnout (Silva, 1990). From the American Medical Society for Sports Medicine (DiFiori et al., 2014), "burnout is part of a spectrum of conditions that includes overreaching and overtraining” (p.5). Meanwhile, Cervelló (2003) established a correspondence between the process of overtraining and burnout, in a way that establishes a parallel in the appearance process of both syndromes. Stress is the trigger element of both processes, but the author indicates that the interpretation that the athlete makes of this is what differentiates the development of burnout from overtraining syndrome.

The first definitions of burnout in sport emerged in the 80 s, but it was not until the late 90s that a consensus was established about what burnout was within the sporting context (Cresswell \& Eklund, 2006; Gould, Udry, Tuffey, \& Loehr, 1996). According to Goodger, Gorely, Lavallee and Harwood (2007), the conceptual unification was achieved after a three-dimensional definition was proposed by Raedeke (1997), characterised by: emotional / physical exhaustion (EFE), sport devaluation (D) and reduced sense of accomplishment (RSA). EFE is defined as feelings of extreme fatigue (physical and psychological) most of the time. D includes negative attitudes toward sport practice. Finally, RSA is reduced accomplishment in terms of sport performance.

Several studies have examined the relationship of burnout or its dimensions with different demographic and sport variables such as gender, age, type of sport, training volume and years of participation. Recent research has found differences in relation to gender, showing that women have the highest values of burnout (Heidari, 2013; Nafian, Karimi, Ghasemi, \& Zahrabi, 2014) and EFE (De Francisco, Garcés de los Fayos, \& Arce, 2014). Regarding age, research has yielded conflicting results. Raedeke and Smith (2001) reported higher levels of burnout in young athletes, Pedrosa and García-Cueto (2014) found higher levels of burnout in adult athletes and De Francisco et al. (2014) was unable to find any relationship between age and the different dimensions of burnout. As for the type of sport, classical authors (Coakley, 1992; Smith, 1986) stated that burnout seems to be more common in athletes of individual sports compared with those who participated as part of a team. However, Gustafsson, Kenttä, Hassmén, and Lundqvist (2007) using a sample of adolescents failed to confirm this. Positive relationships between burnout (Kellmann \& Kallus, 2001; Kenttä, Hassmén, \& Raglin, 2001) or with its EFE dimension (De Francisco et al., 2014), and load and / or training volume have been found, but not with the amount of years of participation (Holden, Keshock, Forester, Pugh, \& Heitman, 2016).

In the light of these results, this study aims to provide data on the prevalence of symptoms of exercise dependence and burnout, and to investigate the relationship between the two variables since it is unknown and may be useful for the development of prevention strategies within the sport context. Finally, the influence of different sociodemografic and sport variables on dependence and burnout will be analysed, as they have generated controversy in previous research.

\section{Method}

\section{Design}

This research presents an ex post facto transversal design. It informs of prevalence of symptoms of exercise dependence and burnout. Also, it explores the relationships of variables related to dependence and burnout in a sample of athletes.

\section{Participants}

The study was conducted using a sample of 449 Spanish athletes from various sport disciplines, 320 males and 129 females. They were aged between 14 and 60 years old (Age: $M=19.71, S D=6.62) .27 .6 \%$ were participants of individual sports such as athletics, fencing, dance sport and artistic gymnastics (the majority being karate with $5.6 \%$ of athletes). $72.4 \%$ of the athletes participated in team sports such as football, rugby and tennis (the majority were players of basketball with a $38.5 \%$ representation). $29.2 \%$ of the athletes had participated in their sport for less than 4 years and $70.8 \%, 4$ or more. Weekly training ranged between 2 and 16 sessions $(M=3.91, S D=2.10)$. The inclusion criteria established that they were athletes older than 14 years with a minimum training condition of two sessions per week and one hour per session.

\section{Instruments}

A questionnaire was used with items about sociodemographic data (age and gender) and sports data (weekly training sessions and type of sport).

The Spanish version of the Exercise Dependence Scale- 
Revised (EDS-R; Sicilia \& González-Cutre, 2011) was given to the participants. The scale consists of 21 items which referred to beliefs and behaviour that have occurred over the past three months, with answers numbered from 1 (never) to 6 (always) in Likert scale format. The scale allows for an overall score of dependence to be obtained (the higher the score, the greater risk of dependence) and a score for each of the seven symptoms that define it (three items per subscale): tolerance (e.g., "I continually increase my exercise intensity to achieve the desired effects/benefits"), withdrawal (e.g., "I exercise to avoid feeling anxious"), intention effects (e.g., "I exercise longer than I plan"), lack of control (e.g., "I am unable to reduce how intense I exercise"), reduction in activities (e.g., "I think about exercising when I should be concentrating on school/work"), exercise time (e.g., "I spend most of my free time exercising"), and continuance (e.g., "I exercise when injured"). This scale allows us to classify individuals by risk of dependency (RD), symptomatic but independent (SID) and asymptomatic independent (AID). The RD group is formed of individuals with scores higher than 5 in three criteria. The SID group is formed by those with scores of 3 to 4 in three or more criteria or obtain scores of 5 to 6 combined with scores of 3 to 4 in three criteria, without reaching the requirements to be included in the RD group. The AID group is formed by individuals with a minimum score of one to two in at least three criteria, without reaching the requirements of incorporation in the SID group. Internal test reliability (Cronbach's alpha) for this instrument in this research is greater than .70 .

The Spanish adaptation of the Athlete Burnout Questionnaire (ABQ) was also used. The nine items designed by De Francisco (2015) are based on the three-dimensional theory of the burnout syndrome. The components EFE (three items, example item: "I feel overly tired from my [sport] participation"), RSA (three items, example item: "I'm accomplishing many worthwhile things in [sport]") and D (three items, example item: "I feel less concerned about being successful in [sport] tha I used to"). The response scale is also in the Likert format with five ordered categories: Almost Never (1), Rarely (2), Sometimes (3), Frequently (4), and Almost always (5). Two items of RSA subscale are scored in the opposite direction to the others, making it necessary to reverse their answers before calculating the total subscale. The higher the sum of the scores in the subscales, the greater the burnout experienced. Depending on $\mathrm{T}$ scores, the risk of each dimension is established following criteria: 1) low risk (athletes whose $\mathrm{T}$ score is equal to or less than to 50 ); 2 ) moderate risk (athletes with $\mathrm{T}$ scores between 50 and 60); 3) high risk (athletes with scores $\mathrm{T}$ between 60 and 70), and 4) with symptoms (athletes with scores $\mathrm{T}$ greater than 70 ). The internal reliability measured in this study by Cronbach's Alpha shows the following values referring to each dimension: $\mathrm{EFE}=.80, \mathrm{RSA}=.74$, and $\mathrm{D}=.77$.

\section{Procedure}

After establishing a date with clubs or federations, research team members administered the questionnaires to athletes before a training session. All participants, or responsible sports tutor in the case of minors, gave their informed consent to participate in the research. Neverthless, before to collect the data, the study was approved by Ethical Committee of the university. After a standardised presentation and institutional approval of the protocol, athletes responded a booklet with the measurement instruments.

\section{Data analysis}

Using SPSS Statistics 21.0 software package (IBM Statistics), a descriptive analysis was carried out. This included means, standard deviation, frequencies and percentages to determine the prevalence of the symptoms of dependence on physical exercise and the dimensions of burnout. Pearson's correlation coefficient was then used for the verification of the relationships between these variables, as well as mean comparison tests to analyse the influence of gender, age, sport dedication and sport for dependence and burnout; $\mathrm{t}$ test for independent samples (subgroup differences; $t$ Student for exercise dependence and Mann-Whitney $U$ test for burnout because of non normality). For the purposes of interpretation and analysis of data a significance level of $p<$ .05 was assumed.

\section{Results}

Table 1 shows the descriptive analysis related to the physical exercise dependence of the participants, where $8.7 \%$ show risk of exercise dependence, $61.5 \%$ show symptoms and $29.8 \%$ are asymptomatic. Regarding gender, the percentages are similar $(8.5 \%$ male and $8.8 \%$ female), however, participants aged under 18 years of age show a higher percentage of exercise dependence $(10.8 \%$ under the age of 18 and $6.8 \%$ over 18). Also, in the Table 1, values of chi-square statistic are included in order to check whether the observed differences reach statistical significance or not.

Table 1. Descriptive data on the prevalence of symptoms of dependence on physical exercise by gender and age group, expressed in percentages (number of subjects in parenthesis).

\begin{tabular}{|c|c|c|c|c|c|c|}
\hline & & Risk of dependence & Not dependent symptomatic & Asymptomatic & Total & $\chi^{2}$ \\
\hline \multirow{2}{*}{ Gender } & Women & $8.5(11)$ & $57.4(74)$ & $34.1(44)$ & $100(129)$ & 1.932 \\
\hline & Men & $8.8(28)$ & $63.1(202)$ & $28.1(90)$ & $100(320)$ & \\
\hline Total & & $8.7(39)$ & $61.5(276)$ & $29.8(134)$ & $100(449)$ & \\
\hline \multirow{2}{*}{ Age Groups } & $<18$ & $10.8(23)$ & $66.2(141)$ & $23(49)$ & $100(213)$ & 3.357 \\
\hline & $\geq 18$ & $6.8(16)$ & $57.2(135)$ & $36(85)$ & $100(236)$ & \\
\hline Total & & $8.7(39)$ & $61.5(276)$ & $29.8(134)$ & $100(449)$ & \\
\hline
\end{tabular}


In relation to the dimensions of burnout, the percentages for suffering from them are between 4\% for EFE and $4.9 \%$ for RSA and D. Regarding gender, men show higher rates than women in all dimensions, showing major differences in D $(0.8 \%$ for women vs. $6.6 \%$ for men). Differentiating by age group, the percentages are equal for EFE (4.2\%) but for the remaining dimensions, over 18's show a higher percentage $(6.4 \%$ and $5.9 \%$ for RSA and $\mathrm{D}$ vs. $3.3 \%$ and $3.8 \%)$. In table 2, the rest of the risk level percentages for each dimension (low, moderate and high) are also displayed, as well as the values of the chi-square statistic-

To analyse the relationship between exercise dependence and burnout with the sociocultural sport variables, a comparison of the means was carried out between exercise dependence characteristics and dimensions of burnout by gender of athletes, age, sport dedication and type of sport.

Table 2. Descriptive data of the prevalence of the dimensions of burnout in athletes by gender and age group, expressed in percentage (number of subjects in parenthesis).

\begin{tabular}{|c|c|c|c|c|c|c|c|}
\hline & & Low risk & Moderate risk & Hig risk & Symptoms & Total & $\chi^{2}$ \\
\hline \multirow[t]{2}{*}{ RSA Gender } & women & $67.4(87)$ & $18.6(24)$ & $10.1(13)$ & $3.9(5)$ & $100(129)$ & \\
\hline & men & $47.2(151)$ & $37.2(119)$ & $10.3(33)$ & $5.3(17)$ & $100(320)$ & $17.476^{*}$ \\
\hline \multirow[t]{2}{*}{ RSA Age Groups } & $<18$ & $55.9(119)$ & $32.4(69)$ & $8.5(18)$ & $3.3(7)$ & $100(213)$ & \\
\hline & $\geq 18$ & $50.4(119)$ & $31.4(74)$ & $11.9(28)$ & $6.4(15)$ & $100(236)$ & 4.090 \\
\hline RSA total & & $45.3(238)$ & $31.8(143)$ & $10.2(46)$ & $4.9(22)$ & $100(449)$ & \\
\hline \multirow[t]{2}{*}{ EFE Gender } & women & $58.1(75)$ & $28.7(37)$ & $10.1(13)$ & $3.1(4)$ & $100(129)$ & \\
\hline & men & $58.1(186)$ & $30.9(99)$ & $6.6(21)$ & $4.4(14)$ & $100(320)$ & 2.027 \\
\hline \multirow[t]{2}{*}{ EFE Age Groups } & $<18$ & $59.6(127)$ & $29.6(63)$ & $6.6(14)$ & $4.2(9)$ & $100(213)$ & \\
\hline & $\geq 18$ & $56.8(134)$ & $30.9(73)$ & $8.5(20)$ & $4.2(9)$ & $100(236)$ & .806 \\
\hline EFE total & & $58.1(261)$ & $30.3(136)$ & $7.6(34)$ & $4(18)$ & $100(449)$ & \\
\hline \multirow[t]{2}{*}{ D Gender } & women & $76(98)$ & $17.1(22)$ & $6.2(8)$ & $0.8(1)$ & $100(129)$ & \\
\hline & men & $63.4(203)$ & $17.8(57)$ & $12.2(39)$ & $6.6(21)$ & $100(320)$ & $11.615^{*}$ \\
\hline \multirow[t]{2}{*}{ D Age groups } & $<18$ & $77.5(165)$ & $13.1(28)$ & $5.6(12)$ & $3.8(8)$ & $100(213)$ & \\
\hline & $\geq 18$ & $57.6(136)$ & $21.6(51)$ & $14.8(35)$ & $5.9(14)$ & $100(236)$ & $21.260 *$ \\
\hline D total & & $67(301)$ & $17.6(79)$ & $10.5(47)$ & $4.9(22)$ & $100(449)$ & \\
\hline
\end{tabular}

* Note: $p<.01$.

The results show statistically significant differences in exercise dependence in terms of age $(t=2.66, p=.001)$, showing the youngest (under 18 years of age) having an increased risk of exercise dependence. There are no significant differences in gender, sport dedication and type of sport (table 3).

Table 3. Descriptive and inferential statistics of dependence in regards to gender, age, weekly training sessions and sport type.

\begin{tabular}{|c|c|c|c|c|c|c|c|c|}
\hline Variables & & $n$ & $M$ & $S D$ & $t$ & $p$ & $\mathrm{CI}$ & ES \\
\hline \multirow{8}{*}{ EDS-R } & Women & 129 & 68.62 & 16.48 & \multirow[t]{2}{*}{.85} & \multirow[t]{2}{*}{.39} & $65.76-71.49$ & \multirow[t]{2}{*}{.1} \\
\hline & Men & 320 & 70.17 & 17.86 & & & 68.3-72.24 & \\
\hline & $<18$ & 213 & 72.03 & 17.57 & \multirow[t]{2}{*}{2.66} & \multirow[t]{2}{*}{$.001^{*}$} & $69.79-74.55$ & \multirow[t]{2}{*}{.26} \\
\hline & $\geqq 18$ & 236 & 67.65 & 17.15 & & & 65.45-69.86 & \\
\hline & $<4$ & 242 & 69.61 & 19.01 & \multirow[t]{2}{*}{-2.40} & \multirow[t]{2}{*}{.81} & $64.69-71.28$ & \multirow[t]{2}{*}{.02} \\
\hline & $\geq 4$ & 207 & 70.01 & 15.59 & & & $68.69-72.39$ & \\
\hline & Individual & 124 & 71.67 & 18.41 & \multirow[t]{2}{*}{1.45} & \multirow[t]{2}{*}{.14} & $60.89-67.16$ & \multirow[t]{2}{*}{.15} \\
\hline & Team & 325 & 68.99 & 17.07 & & & $70.15-73.85$ & \\
\hline
\end{tabular}

* Note: $p<.01 ; S D=$ standard deviation; $\mathrm{CI}=$ confidence interval; ES = effect size

Regarding the indicators of burnout, women show lower average scores than men in $\operatorname{RSA}(Z=16,772.5 ; p=.002)$ and $\mathrm{D}(Z=17,311.5 ; p=.006)$. On the other hand, older athletes exhibit higher mean scores in $\mathrm{D}(Z=19,065.5 ; p=.001)$. As for dedication to sport, participants who spend more than 4 sessions a week on their workouts show a lower average score in $\operatorname{RSA}(Z=19,972.5 ; p=.0001)$ but higher in $\mathrm{E}(Z=$
$20,474 ; p=.001)$. Statistically significant differences also appear depending on the modality of the sport (individual/ team) in RSA $(Z=16,776 ; p=.005)$, showing athletes who take part in team sports have a higher average range compared to athletes who participate on an individual basis (table 4). 
Table 4. Descriptive and inferential statistics of dimensions of burnout in regards to gender, age, weekly training sessions and sport type.

\begin{tabular}{|c|c|c|c|c|c|c|c|}
\hline Dimensions & & $n$ & Sum average range & $Z$ & $p$ & CI & $\mathrm{ES}$ \\
\hline \multirow{8}{*}{ RSA } & Women & 129 & 195.02 & $16,772.5$ & $.002 *$ & $3.84-4.09$ & .30 \\
\hline & Men & 320 & 237.09 & & & $3.68-3.83$ & \\
\hline & $\overline{<18}$ & 213 & 214.83 & $22,968.5$ & .111 & $3.79-3.96$ & .37 \\
\hline & $\geq 18$ & 236 & 234.18 & & & $3.67-3.86$ & \\
\hline & $\overline{<} 4$ & 242 & 245.97 & $19,972.5$ & $.001 *$ & $1.63-1.85$ & .34 \\
\hline & $\geq 4$ & 207 & 200.49 & & & $1.50-1.68$ & \\
\hline & $\overline{\overline{\text { Individual }}}$ & 124 & 197.79 & 16,776 & $.005^{*}$ & $3.83-4.09$ & .30 \\
\hline & Team & 325 & 235.38 & & & $3.69-3.84$ & \\
\hline \multirow{8}{*}{ EFE } & Women & 129 & 214.72 & 19,314 & .282 & $1.87-2.20$ & .11 \\
\hline & Men & 320 & 229.14 & & & $2.01-2.20$ & \\
\hline & $<18$ & 213 & 215.74 & $23,162.5$ & .147 & $1.91-2.14$ & .14 \\
\hline & $\geq 18$ & 236 & 233.35 & & & $2.03-2.26$ & \\
\hline & $\overline{\overline{<4}}$ & 242 & 206.10 & 20,474 & $.001^{*}$ & $1.86-2.09$ & .29 \\
\hline & $\geq 4$ & 207 & 247.09 & & & $2.10-2.34$ & \\
\hline & Individual & 124 & 213.58 & $18,733.5$ & .245 & $1.85-2.15$ & .12 \\
\hline & Team & 325 & 229.36 & & & $2.03-2.22$ & \\
\hline \multirow{8}{*}{$\mathrm{D}$} & Women & 129 & 199.20 & $17,311.5$ & $.006^{*}$ & $1.37-1.58$ & .34 \\
\hline & Men & 320 & 235.40 & & & $1.65-1.84$ & \\
\hline & $<18$ & 213 & 196.51 & $19,065.5$ & $.001 *$ & $1.42-1.62$ & .16 \\
\hline & $\geq 18$ & 236 & 250.71 & & & $1.70-1.91$ & \\
\hline & $<4$ & 242 & 229.73 & $23,902.5$ & .388 & $1.63-1.85$ & .19 \\
\hline & $\geq 4$ & 207 & 219.47 & & & $1.50-1.68$ & \\
\hline & $\overline{\overline{\text { Individual }}}$ & 124 & 218.44 & 19,337 & .494 & $1.47-1.70$ & .17 \\
\hline & Team & 325 & 227.50 & & & $1.61-1.80$ & \\
\hline
\end{tabular}

* Note: $p<.01 ; \mathrm{CI}=$ confidence interval; $\mathrm{ES}=$ effect size; RSA = reduced sense accomplishment; $\mathrm{EFE}=$ emotional/ physical exhaustion; $\mathrm{D}=$ sport deval-
uation.

Concerning the relationship between exercise dependence and burnout, the results show that exercise dependence has a positive relationship (correlation significance .01) with the dimensions EFE and D, the highest (although lowmoderate) corresponding to EFE and a low negative relationship with RSA (table 5).

Table 5. Correlations between exercise dependence indicators and dimensions of burnout.

\begin{tabular}{lcccc}
\hline & EDS-R & RSA & EFE & D \\
\hline EDS-R & -- & & & \\
RSA & $-.149^{*}$ & -- & & \\
EFE & $.290^{*}$ & -.011 & -- & \\
D & $.130^{*}$ & $.142^{*}$ & $.406^{*}$ & -- \\
\hline
\end{tabular}

$*$ Note: $p<.01 ; \mathrm{RSA}=$ reduced sense accomplishment; EFE $=$ emotional $/$ physical exhaustion; $\mathrm{D}=$ sport devaluation.

\section{Discussion}

The aim of the research was to analyse the prevalence and relationship between the symptoms of exercise dependence and burnout in athletes, as well as to investigate its relationship with other variables such as gender, age, sport dedication, and type of sport of the participants in the study.

The results show a higher percentage of dependence than those referred to by Allegre, Souville, Therme and Griffiths (2006) who found the risk of dependence was less than $5 \%$. Well above the $2.7 \%$ recently found by Zeulner, Ziemainz, Beyer, Hammon and Janka (2016). However, other studies have found higher prevalence, placing the percentage at
$13.6 \%$ in endurance athletes (Latorre, Jiménez, Párraga, \& García, 2016). Marques, Peralta and Catuda (2015) suggest that, although exercise dependence is a rare condition, it is triggered in professionals or semi-professionals related with sport between $26 \%$ and $34 \%$.

Regarding the prevalence of the dimensions of burnout, De Francisco et al. (2014) found similar results when studying the prevalence of burnout through its three-dimensional conceptualisation, presenting in this study slightly more than one percentage point in RSA and less than one point (.7) for D. In general, few studies report percentages of the dimensions that make up the syndrome, with most studies providing data on burnout total or descriptive statistics for the three burnout dimensions.

Regarding the results found about the sociodemographic variables, no significant differences in exercise dependence were found in the same line as the recent study by Reche et al. (2015). Allegre et al. (2007) also found no differences regarding gender, highlighting this result as contrary to previous research where females showed higher values of dependence. These authors suggest that differences might not have been detected due to low representation of females in the sample $(9 \%)$. Continuing with gender differences, for burnout, males show higher percentages for RSA and D, with no statistically significant differences in EFE. Nafian et al. (2014) point to gender role theories to explain the high levels of depersonalisation that the males showed in their sample because they tend not to show their emotions and to 
distance themselves, which could be applied to the results of this study.

As for the age of the athletes, results indicate that athletes under 18 years show a greater dependence on physical exercise. Similar data is presented in the study by GonzálezCutre and Sicilia (2012) in which the highest level of dependence is for young Spanish fitness centre users. Regarding the relationship between age and the dimensions of burnout, only significant results regarding $\mathrm{D}$ were found, where older athletes exhibit greater sport devaluation, which is consistent with the study by Casagrande, Andrade, Viana and Vasconcellos (2014), where older players showed higher averages in D. Meanwhile, Pedrosa and García-Cueto (2014) found higher levels of total burnout in adult athletes, and explained this on the grounds that greater demands in sports begin to appear when athletes leave adolescence.

As for sports dedication, it is not significantly associated with dependence exercise and therefore it is not proved to be joined with more training during the same day or more days of training, this is supported by Kjelsås et al. (2003) who do not consider high dedication to sport sufficient to create dependence exercise. Regarding burnout, studies indicate that more training demands result in higher levels of burnout (Gustafsson et al., 2007; Kellmann and Kallus, 2001; Kenttä et al., 2001; Silva, 1990). De Francisco et al. (2014) indicate that most athletes, who train, show high levels of EFE, a fact that is corroborated in this study. It has not been the case for RSA where the highest values are for those who train for less than four hours and who therefore have a lower level of technique that in turn results in a lower sense of accomplishment. Casagrande et al. (2014) found results along this line, stating that athletes could be reducing the volume of training to feel they were not achieving the goals established.

The sport modality (individual or team) is not shown as a relevant variable in relation to dependence. Reche et al.

\section{References}

Adams, J. M., Miller, T. W., \& Kraus, R. F. (2003). Exercise dependence: diagnostic and therapeutic issues for patients in psychotherapy. Journal of Contemporary Psychotherapy, 33(2), 93-107.

Allegre, B., Souville M., Therme P., \& Griffiths M. (2006). Definitions and measures of exercise dependence. Addiction Research and Theory, 14, 631646. https://doi.org/10.1080/16066350600903302.

Allegre, B., Therme, P., \& Griffiths, M. (2007). Individual factors andthe context of physical activity in exercise dependence: A prospective study of 'ultra-marathoners'. International Journal of Mental Health and Addiction, 5(3), 233-243. https://doi.org/10.1007/s11469-007-9081-9

Caracuel, E., \& Arbinaga, I. (2010). Repercusión del ejercicio físico sobre la salud. Apuntes de Psicología, 28(2), 315-328.

Casagrande, P.O., Andrade, A., Viana, M. S., \& Vasconcellos, D. I. C. (2014). Burnout em tenistas brasileiros infanto-juvenis. Motricidade, 10(2), 60-71.https://doi.org/10.6063/motricidade.10(2).2713.

Cervelló, E. (2003). Sobreentrenamiento, burnout y motivación en el deporte. In F. Suay (Ed.), El sindrome de sobreentrenamiento: una visión desde la Psicobiología del Deporte (pp. 39-54). Barcelona: Paidotribo.

Coakley, J. (1992). Burnout among adolescent athletes: A personal failure or social problem. Sociology of sport journal, 9(3), 271-285. https://doi.org/10.1123/ssj.9.3.271.
(2015) came to the same conclusion. Sport modality do is relevant to burnout, specifically for RSA (athletes of team sports suffer more RSA). Previous studies indicate that it is more common in individual modalities (Coakley, 1992; Smith, 1986) but also in collective modalities (Pedrosa \& García-Cueto, 2014), as it has been in this case. Pedrosa and García-Cueto (2014) suggest that collective athletes have a lower margin of influence on the results and successes to achieve than individual athletes.

Finally, it has been shown that exercise dependence relates positively with all dimensions of burnout, which requires a thorough study to analyse the specific role of dependence on the different dimensions of burnout, as the relationship is not solely due to training, since, if this were so, it would show significances only with EFE and not with the other dimensions of more psychological character. In addition, an inverse relationship with D is observed, and is explained by the fact that, with training, dependence and feelings of achievement are increased.

This research has several limitations. First, the sample size is relatively large, but also very heterogeneous. Second, an interaction between sociodemografic or sport variables and dependence or burnout could be present. Different studies (Cremades \& Wiggins, 2008; Gustafsson et al., 2007), showed an interaction that occurs between gender and type of sport over burnout. This research is a preliminary study so it would be interesting to investigate further and conduct analysis in this area since as indicated by Judge, Bell, Theodore, Simon and Bellar (2012): "women expressed more burnout than did men in some situations, but not others" (p. 236).

Funding: This work was supported by the Universidad Católica de Murcia (PMAFI 14/14).

Cremades, J. G., \& Wiggins, M. S. (2008). Direction and intensity of trait anxiety as predictors of burnout among collegiate athletes. Atbletic Insight: The Online Journal of Sport Psychology, 10(2).

Cresswell, S. L., \& Eklund, R. C. (2006). The nature of player burnout in rugby: Key characteristics and attributions. Journal of Applied Sport Psychology, 18, 219-239. https://doi.org/10.1080/10413200600830299.

De Francisco, C. (2015). Versión reducida del Athlete Burnout Questionnaire $(\mathrm{ABQ})$ : propiedades psicométricas preliminares. [Reduced version of the Athlete Burnout Questionnaire (ABQ): preliminary psychometric properties]. Revista de Psicología del Deporte, 24,177-183.

De Francisco, C., Garcés de los Fayos, E. J., \& Arce, C. (2014). Burnout en deportistas: prevalencia del síndrome a través de dos medidas. [Burnout in athletes: Prevalence of the syndrome through two measures]. Cuadernos de Psicología del Deporte, 14(1), 29-38.

DiFiori, J. P., Benjamin, H. J., Brenner, J. S., Gregory, A., Jayanthi, N., Landry, G. L., \& Luke, A. (2014). Overuse injuries and burnout in youth sports: a position statement from the American Medical Society for Sports Medicine. British journal of sports medicine, 48(4), 287-288. http://dx.doi.org/10.1136/bjsports-2013-093299.

Ekkekakis, P., \& Acevedo, E.O. (2006). Affective responses to acute exercise: Toward a psychobiological dose-response model. In E.O. Aceve- 
do \& P. Ekkekakis (Eds.), Psychobiology of physical activity (pp. 91-109). Champaign, IL: Human Kinetics.

González-Cutre, D., \& Sicilia, A. (2012). Dependencia del ejercicio físico en usuarios españoles de centros de acondicionamiento físico (fitness): diferencias según el sexo, la edad y las actividades practicadas. [Burnout in athletes: Prevalence of the syndrome through two measures]. Behavioral Psychology/ Psicologia Conductual, 20(2), 349-364.

Goodger, K., Gorely, T., Lavallee, D., \& Harwood, C. (2007). Burnout in sport: A systematic review. The Sport Psychologist, 21, 127-151. https://doi.org/10.1123/tsp.21.2.127.

Gould, D., Udry, E., Tuffey, S., \& Loehr, J. (1996). Burnout in competitive junior tennis players: I. A quantitative psychological assessment. The Sport Psychologist, 10, 322-340.

Gustafsson, H., Kenttä, G., Hassmén, P., \& Lundqvist, C. (2007). Prevalence of burnout in competitive adolescent athletes. The Sport Psychologist, 21(1), 21-37. https://doi.org/10.1123/tsp.21.1.21.

Guszkowska, M., \& Rudnicki, P. (2012). Mood changes in physically active men in situations of imagined discontinuation of physical exercises as an indication of the risk of addiction to physical exercises. Polish Journal of Sport and Tourism, 19(1), 16-20. https://doi.org/ 10.2478/v10197012-0003-4.

Heidari, S. (2013). Gender differences in burnout in individual athletes. European Journal of Experimental Biology, 3(3), 583-588.

Holden, S. L., Keshock, C. M., Forester, B. E., Pugh, S. F., \& Heitman, R. J. (2016). Burnout and Years of Sports Competition: Is There a Correlation? International Journal of Sports Science, 6(1A), 8-11. doi: 10.5923/s.sports.201601.02

Jiménez, M. G., Martínez, P., Miró, E., \& Sánchez, A. I. (2008). Bienestar psicológico y hábitos saludables: ¿están asociados a la práctica de ejercicio físico? International Journal of Clinical and Health Psychology, 8(1), 185202.

Jones, C. M., \& Tenenbaum, G. (2009). Adjustment Disorder: a new way of conceptualizing the overtraining syndrome. International Review of Sport and Exercise Psychology, 2(2), 181-197.

Judge, L. W., Bell, R. J., Theodore, R., Simon, L., \& Bellar, D. (2012). An exploratory examination of burnout in NCAA Division II athletes. Journal of Intercollegiate Sport, 5(2), 230-240. https://doi.org/10.1123/jis.5.2.230.

Kellmann, M., \& Kallus, K.W. (2001). Recovery-stress questionnaire for atbletes: User manual. Champaign, IL: Human Kinetics.

Kenttä, G., Hassmén, P., \& Raglin, J. S. (2001). Training practices and overtraining syndrome in Swedish age-group athletes. International Journal of Sports Medicine, 22, 460-465.

Kjelsas, E., Augestad, L. B., \& Gotestam, K.G. (2003). Exercise dependence in physically activa women. The European Journal of Psycbiatry, 17, $145-155$.

Klein, D. A., Bennett, A. S., Schebendach, J., Foltin, R. W., Devlin, M. J., \& Walsh, B. T. (2004). Exercise "addiction" in anorexia nervosa: Model development and pilot data. CNS Spectrums, 9, 531-537. https://doi.org/10.1017/S1092852900009627.

Latorre, P. Á., Jiménez, A., Párraga, J., \& García, F. (2016). Dependencia al ejercicio físico e insatisfacción corporal en diferentes deportes de resistencia y su relación con la motivación al deporte. Revista de Psicología del Deporte, 25(1), 113-120.

Lindwall, M., \& Palmeira, A. (2009). Factorial validity and invariance testing of the Exercise Dependence Scale-Revised in Swedish and Portuguese exercisers. Measurement in Physical Education and Exercise Science, 13, 166179 .

Lubans, D. R., Foster, C., \& Biddle, S. J. H. (2008). A review of mediators of behavior in interventions to promote physical activity among children and adolescents. Preventive Medicine, 47, 463-470. https://doi.org/10.1016/j.ypmed.2008.07.011.

Marques, A., Peralta, M., \& Catuda, R. (2015). Dependência em exercício físico: uma análise na perspetiva da saúde pública. Boletim SPEF, 39, 8999.

Márquez, S., \& de la Vega, R. (2015). La adicción al ejercicio: un trastorno emergente de la conducta. Nutrición Hospitalaria, 31(6), 2384-2391. https://doi.org/10.3305/nh.2015.31.6.8934.

Modolo, V. B., Mello, M. T. D., Giménez, P. R. B. D., Tufik, S., \& Antunes, H. K. M. (2009). Dependencia de exercicio fisico: humor, qualidade de vida em atletas amadores e profissionais. Revista Brasileira de Medicina do Esporte, 15(5), 355-359.https://doi.org/10.1590/S151786922009000600007.

Nafian, S., Karimi, E., Ghasemi, M., \& Zahrabi, S. (2014). The effect of gender and sport field type on burnout levels in Iranian athletes. Archi ves of Applied Science, 6(4), 11-14.

Pedrosa, I., \& García-Cueto, E. (2014). Estudio del síndrome de burnout en deportistas: prevalencia y relación con el esquema corporal. [A Study of the Burnout Syndrome in Sportspeople: Prevalence and Relationship to the Body Image]. Universitas Psychologica, 13(1), 135-143. https://doi.org/10.11144/Javeriana.UPSY13-1.esbd.

Raedeke, T. D. (1997). Is athlete burnout more than just stress? A sport commitment perspective. Journal of Sport and Exercise Psychology, 19(4), 396-417.

Raedeke, T. D., \& Smith, A. L. (2001). Development and preliminary validation of an athlete burnout measure. Journal of Sport \& Exercise Psychol ogy, 23(4), 281-306. https://doi.org/ 10.1123/jsep.23.4.281.

Reche, C., \& Gómez, M. (2014). Dependencia al ejercicio físico y trastornos de la conducta alimentaria. [Dependence of physical exercise and eating disorders]. Apuntes de Psicología, 32(1), 25-32.

Reche, C., Martínez-Rodríguez, A., \& Ortín, F. J. (2015). Dependencia al ejercicio físico e indicadores del estado de ánimo en deportistas universitarios. [Exercise dependence and mood states indicators in university athletes]. Cuadernos de Psicología del Deporte, 15(2), 21.

Sicilia, A., \& González-Cutre, D. (2011). Dependence and physical exercise: Spanish Validation of the Exercise Dependence Scale-Revised (EDSR). Spanish Journal of Psychology, 14(1), 421-431. https://doi.org/10.5209/rev_SJOP.2011.v14.n1.38.

Silva, J. M. (1990). An analysis of the training stress syndrome in competitive athletics. Journal of Applied Sport Psychology, 2(1), 5-20.

Smith, R. E. (1986). Toward a cognitive-affective model of athletic burnout. Journal of Sport Psychology, 8(1), 36-50. https://doi.org /10.1123/jsp.8.1.36.

Weik, M., \& Hale, B. D. (2009). Contrasting gender differences on two measures of exercise dependence. British Journal of Sports Medicine, 43(3), 204-207. https://doi.org /10.1136/bjsm.2007.045138.

Zeulner, B., Ziemainz, H., Beyer, C., Hammon, M., \& Janka, R. (2016). Disordered Eating and Exercise Dependence in Endurance Athletes. Advances in Physical Education, 6, 76-87. https://doi.org /10.4236/ape.2016.62009.

(Article received: 28-03-2017; revised: 12-05-2017; accepted: 23-05-2017) 